\title{
Students' Engagement in Online Language Learning Through Short Video Lessons
}

\author{
M. ${ }^{a}$ Dolores Castrillo de Larreta-Azelain \\ Elena Martín Monje \\ Universidad Nacional de Educación a Distancia (UNED)
}

Received: 26 July 2015 / Accepted: 7 February 2016

ISSN: $1697-7467$

\begin{abstract}
This research is part of a network for teaching innovation put forward by Universidad Nacional de Educación a Distancia (UNED, Spain), aimed at improving students' foreign language competence through the integration of short video lessons in several language courses. The results show heterogeneity in the different languages, both in the number of videos deemed necessary for the course and the tools preferred for the preparation of the audiovisual material. As for the students' perception of their own progress in language proficiency, they reported an increased motivation and engagement, which resulted in a perceived improvement in their oral skills, lexis and grammar, but not so much in their written production.
\end{abstract}

Key words: linguistic competence, foreign languages, video lessons, online learning.

La participación de los estudiantes en el aprendizaje de lenguas en línea a través de vídeo clases breves

RESUMEN: Esta investigación forma parte de una red de innovación docente llevada a cabo en la Universidad Nacional de Educación a Distancia (UNED, España), con el fin de mejorar el aprendizaje de lenguas extranjeras a través de la integración de vídeo clases breves en varios cursos de idiomas. Los resultados muestran heterogeneidad según los diferentes idiomas, tanto en el número de vídeos que se consideran necesarios para el curso como en las herramientas preferidas para la preparación del material audiovisual. En cuanto a la percepción de los estudiantes de su propio progreso en el dominio de la lengua, han mostrado un aumento en la motivación y participación, y perciben que esto se ha traducido en una mejora de su competencia oral, vocabulario y gramática, pero no tanto en su producción escrita.

Palabras clave: competencia lingüística, lenguas extranjeras, vídeo clases, aprendizaje en línea.

\section{INTRODUCTION}

This educational initiative is part of the Research Networks for Teaching Innovation, put forward by the Spanish University for Distance Education (UNED) with the aim of encouraging innovative practices in tertiary education in Spain. This program is part of the European Higher Education Area (EHEA) framework and covers the following fields: curriculum design based on competences, implementation of active learning methodologies, models for formative evaluation and new forms of tutoring adapted to the EHEA. The project 
presented here belongs to the second type, implementation of active learning methodologies, which is something crucial in our institution, given the profile of our students. The UNED is the main university in Spain to provide distance education to adults and has over 260,000 students, with an average age of over 35 (www.uned.es). Since its beginnings it has strived to apply the latest technological developments to learning, with its own virtual campus, called aLF, and Web-conferencing system (AVIP). Lately it has encouraged teachers and lecturers to create their own multimedia resources, in order to bring the courses offered by the university into the digital era.

The main objective of this research project was, accordingly, to improve the virtual courses in some of the subjects which deal with foreign languages in various degrees at UNED (English Studies, Spanish Language and Literature, and Tourism), through the implementation of short recordings which would be designed and developed by the teaching teams in those courses using different methodological approaches and tools. The research hypothesis put forward was that these mini-videos are adequate materials that can impact positively in the improvement of our distance education students, helping them make steady progress in their foreign language competence. The main objective, thus, can be said to be twofold: 1) to measure the perception of the students in terms of effectiveness and language improvement; 2) to assess the students' adoption of different web conferencing and videorecording tools (AVIP, designed by UNED, Adobe Presenter, YouTube, etc.), all under the perspective of two main objectives of the EHEA: the empowerment through autonomous learning and improvement in foreign language competence.

\section{Literature REVIEW}

In this technologically advanced society the use of video for educational purposes has become commonplace and made a significant difference in the teaching and learning of foreign languages. They have been used in education for almost half a century (Wright, 1976) and proved to be useful and stimulating for language learners (Çakir, 2006, Canning-Wilson, 2000). In the context of EFL (English as a Foreign Language) a number of key factors have been pointed out as fundamental when using videos for language teaching and learning: a) Inspiration/Motivation/Interest: Does the video appeal to the students? Will it make them want to learn?; b) Content: Does the content match the instructional goals?; c) Clarity of message: Is the instructional message clear to the students?; d) Pacing: Is the rate of the language or instruction too fast for the students?; e) Graphics: Do the graphics or images used really help to clarify the message?; f) Length and independence of the video or sequence: Is the video short enough? and $\mathrm{g}$ ) Use of video: implemented methodology.

More recent research (e.g. Engin, 2014) has proved that using videos for teaching language in the flipped classroom model -in which students are exposed to new content outside of the class through short videos, and class time is used to further develop this gained knowledge through problem-solving, discussion, practice, and interaction with peers and teacher- yields positive results, not only because this flipped model 
gives students the opportunity to learn in their own time at their own pace, but also because it notably contributes to improving aspects related to motivation, collaboration and language learning.

Videos can be particularly useful for distance learning, since they facilitate the transfer of knowledge through instructivist strategies, on the one hand, thanks to their expositive nature (Lehmann, 2013), whereas, on the other hand and simultaneously, they provide a feeling of closeness, thus making the learning process more personal (Conole, 2013; Lipson, 2013; Wedekind, 2013). Consequently, the inclusion of videos helps to make up for the seemingly anonymous nature of a virtual learning community, which has traditionally been seen as one of the flaws of online distance learning.

There has been some recent criticism of the use of videos in massive, open, online learning environments such as $\mathrm{xMOOCs}^{1}$ referred, precisely, to the nature of the contents: They are seen to be too narrative and lacking individualization, since all students access the same videos. However, this criticism has been successfully refuted by authors such as Schulmeister (2013), who claims the individualization is achieved through the personal use that each student makes of the provided videos, by possibly re-watching them (Lehmann, 2013), downloading, etc. and therefore gaining a deeper understanding of their contents. Students can adapt their learning pace to their needs and time (or lack of), devising their own learning schedule as best fits their circumstances (Lackner, 2013). The video lessons allow students not just to access the contents on demand but, most importantly, to replay those contents which they may find specially complex at their own pace, hence making learning much more flexible and achievable.

Videos not only provide instances of real language use, their great advantage is that they provide authentic language input (Katchen, 2002) and are recognized to be highly rich sources of linguistic examples. They bring into the classroom a wide range of communicative situations and illustrate new concepts for students, since non-native speakers of a language tend to rely much more on visual clues to support their understanding and learning. This is the case especially when they include specific vocabulary or grammar structures that seem to pose difficulties for students (Jeng, Wang \& Huang, 2009). Videos help to promote comprehension, making meaning clearer by highlighting relationships in a way that is not possible with words. Furthermore, there is documented evidence corroborating the notion that videos motivate learners because they contextualize language naturally, thus enabling learners to experience authentic language in controlled environments (Cakir, 2006). In this sense, Koumi (2009) offers a list of 27 techniques and teaching functions that exploit the videos' distinctive strengths, divided into three domains: 1) assisting learning and skills development; 2) providing vicarious experiences; and 3) nurturing (motivations, feelings). Additionally, Pascual (2011) has identified and classified the four components which comprise a didactic video lesson: 1) a physical medium, 2) content, 3) a symbolic means to represent information, and 4) a teaching goal or purpose. It is worth noting here that in virtual learning environments

\footnotetext{
${ }^{1} \mathrm{xMOOCs}$ are based on instructivist models and on the principles of Mastery learning, as opposed to cMOOCs which are based on the Connectivism put forward by Siemens.
} 
the physical medium would correspond to a digital file.

With regard to the desirable length of videos, the mini-video format or short video lesson has proved to be ideal (Letón et al., 2009). According to these authors these mini-videos are the natural evolution of the recording of a theoretical class, although with a distinctive feature, its short duration (5-10 minutes). This makes them easier to handle and upload to the Internet, making it possible to be reproduced by any portable multimedia device. Further evidence supporting the suitability of short videos may lie in the findings of Guo, Kim \& Rubin (2014), after their extensive empirical study of how video production decisions affect student engagement in online educational environments like MOOCs. They found that shorter and informal talking-head videos are much more engaging, than high-quality, pre-recorded classroom lectures just as the renowned Khan-style ${ }^{2}$ tablet drawings are. This literature review shows that nowadays there is no questioning about how the use of video contributes to methodological variety, attention to diversity and individualized learning, not only in language learning, but in the wide, general educational context.

\section{RESEARCH METHODOLOGY}

\subsection{Scheduling of activities}

This project was carried out throughout a whole academic year with four differentiated stages, as shown in table 1 below:

Table 1. Timeline of project

\begin{tabular}{clll}
\hline October 2012 & Nov.-Dec. 2012 & Dec. 2012-Apr. 2013 & \multicolumn{1}{c}{ May 2013 } \\
\hline - Beginning of project & $\begin{array}{l}\text { - Meetings of teach- } \\
\text { ing teams to agree on } \\
\text { design of recordings }\end{array}$ & $\begin{array}{l}\text { - Recording and } \\
\text { uploading of videos } \\
\text { onto virtual courses }\end{array}$ & $\begin{array}{l}\text { - Final questionnaires } \\
\text { for students \& teach- } \\
\text { ers }\end{array}$ \\
& $\begin{array}{l}\text { - Initial question- } \\
\text { naires for students \& } \\
\text { teachers }\end{array}$ & $\begin{array}{l}\text { - Conclusions \& sug- } \\
\text { gestions for future } \\
\text { research }\end{array}$ \\
\hline
\end{tabular}

\subsection{Data collection techniques}

The data collection was done using a mixed-method approach (Cohen, Manion \& Morrison, 2007; Robson, 2002), using quantitative techniques (student tracking in the virtual course) and qualitative ones (questionnaires before and after the project), with the aim of getting a global view of this educational intervention (Bryman, 2006). Both students and

\footnotetext{
${ }^{2}$ Micro lectures in the form of YouTube videos that show doodles and diagrams on an electronic blackboard. Drawings are made with a tablet and a free natural drawing application. [http://en.wikipedia.org/wiki/Khan_Academy]
} 
teachers had to complete questionnaires during the project, one at the beginning and one at the end. For the purposes of this paper we will focus on the qualitative side of the research, using the questionnaires as baseline. Also, with regard to the design of the research, this study has followed a quasi-experimental outline, a common model in foreign language research: "Quasi-experimental designs (...) are constructed from situations which already exist in the real world, and are probably more representative of the conditions found in educational contexts." (Seliger \& Shohamy, 1990: 148).

\subsection{Participants}

The cohort of participants, taking into account only those that completed all proposed activities, comprised 174 students from the following courses: English for Professional Purposes (Degree in Tourism), Second Language I: French (Degree in Tourism), Foreign Language II: Italian (Degree in English Studies), Second Language II: Modern Greek (Degree in Tourism) and Foreign Language II: German (Degree in English Studies and Degree in Spanish Language and Literature). Table 2 shows the breakdown of courses and number of students:

Table 2. Number of participants in each of the courses included in the project (teachers and students)

\begin{tabular}{lccccc}
\hline \multicolumn{1}{c}{ Course } & Degree & No. Students & $\mathbf{\%}$ & $\begin{array}{c}\text { No. } \\
\text { Teachers }\end{array}$ & $\%$ \\
\hline English for Professional Purposes & Tourism & 93 & $53 \%$ & 4 & $50 \%$ \\
\hline Second Language I: French & Tourism & 25 & $14 \%$ & 1 & $12.5 \%$ \\
\hline Foreign Language II: Italian & English Studies & 22 & $13 \%$ & 1 & $12.5 \%$ \\
\hline Second Language II: Modern Greek & Tourism & 0 & $0 \%$ & 1 & $12.5 \%$ \\
\hline Foreign Language II: German & $\begin{array}{c}\text { English Studies } \\
\text { Spanish Language } \\
\text { \& Literature }\end{array}$ & 34 & $20 \%$ & 1 & $12.5 \%$ \\
\hline & TOTAL & 174 & $100 \%$ & 8 & $100 \%$ \\
\hline
\end{tabular}

\subsection{Outline of activities}

Teachers created the didactic materials as stated in Table 1 and uploaded them to their respective virtual courses. In turn, the students taking part in this project were asked to watch the mini-videos produced, which had content relevant to their language courses. The number of videos varied depending on the course: The majority of the teaching teams recorded over 10 videos in total, but one teacher $(12.5 \%)$ only made one, which shows the heterogeneity in the criteria agreed by the different instructors. As for the content of the videos, they generally dealt with issues related to use of language, but the focus varied depending on the course, as can be seen in Table 3: 
Table 3. Description of the videos

\begin{tabular}{|c|c|c|}
\hline Course & $\begin{array}{l}\text { No. } \\
\text { videos }\end{array}$ & Content of the videos \\
\hline $\begin{array}{l}\text { English for Professional } \\
\text { Purposes }\end{array}$ & 12 & $\begin{array}{l}\text { - In each unit (total of 6) one video introduced the topic } \\
\text { and one focused on issues of special difficulty (gram- } \\
\text { matical, lexical, pragmatic) }\end{array}$ \\
\hline Second Language I: French & 12 & $\begin{array}{l}\text { - In each unit (total of 6) one video introduced the topic } \\
\text { and one focused on issues of special difficulty (gram- } \\
\text { matical, lexical, pragmatic) }\end{array}$ \\
\hline Foreign Language II: Italian & 11 & - All videos dealt with complexities in Italian grammar \\
\hline $\begin{array}{l}\text { Second Language II: Mod- } \\
\text { ern Greek }\end{array}$ & 1 & - Introduction to the course \\
\hline $\begin{array}{l}\text { Foreign Language II: } \\
\text { German }\end{array}$ & 10 & - All videos dealt with complexities in German grammar \\
\hline
\end{tabular}

\section{Data analysis and discussion}

Four questionnaires were prepared in order to analyze the teachers' and students' perception of the project: two for the teaching teams (one before and one after the activity), and two for the students (likewise, one before and after). As for the teachers' responses, it is worth highlighting the heterogeneity in the approaches adopted, mainly in relation to two of the variables: 1) the tools to be used and 2) the number of videos to be recorded.

Adobe Presenter, screencasting software commercialized by Adobe Systems, seemed to be the tool most favoured by teachers: $\mathrm{N}=5 / 62.5 \%$ of them chose it, as opposed to $\mathrm{N}=1 / 12.5 \%$ who preferred YouTube, $\mathrm{N}=1 / 12.5 \%$ who used the in-house recording software AVIP and $\mathrm{N}=1 / 12.5 \%$ who opted for other software. This is probably due to its availability as part of the software package any UNED teacher has access to and also because it has been advertised as an easy way to create more interactive and engaging videos, taking Microsoft PowerPoint slides as the starting point.

There was also some disparity in the number of videos recorded and made available to the group, as well as the criteria followed when deciding the amount of videos for that course. Some teachers made as many videos as didactic units in the course, others made two for each unit (one presenting the unit and another one dealing with an issue of special difficulty, explaining grammatical, lexical and pragmatic elements) and some others just chose especially difficult and/or relevant grammatical aspects covered throughout the course (see Table 3 above). As for the length of the videos, the vast majority ran for less than 10 minutes, which is within the advisable duration for these materials according to research (maximum 10 minutes, see for instance Castrillo, 2014). There were only a couple of videos in the course "English for Professional Purposes" which were over 15 minutes long.

With regard to participants' surveys, students completed both pre- and post-questionnaires. The initial questionnaire was divided into three sections. The first part collected socio-demographic data and information related to the student's foreign language level -taking the CEFR 
(Common European Framework of Reference for Languages) scale as benchmark. The next section of the questionnaire was designed to collect data on student's prior use of audio-visual material for learning and their assessment. Finally, section 3 of the questionnaire intended to evaluate student's expectations of the proposed activity with two closed questions and an open one. The final questionnaire consisted of an introductory collection of demographic data and was divided into four sections. The first part was intended to assess the technical aspects of videos and their format. With a combination of open and closed questions, students were asked, among other things, about the existence of technical problems, and about the devices and programmes used. Furthermore, they were queried on their perception on the duration of the video-classes. In the next section, students were invited by means of a question grid to assess to what extent the activity would have contributed to improving their communicative competence concerning the four language skills (listening, speaking, reading and writing). This survey section also aimed at examining the extent to which students perceived an improvement in different areas of learning, particularly in relation to knowledge of grammatical structures and increased vocabulary range. The fourth part intended to examine students' dedication to the subject in quantitative terms and their resulting motivation after working with mini videos. Finally, in the last section of the questionnaire, the authors collected information on the final assessment of the activity, assessing whether it met students' expectations and whether they would participate again in a similar activity.

A total of 412 students completed the initial survey. Regarding their profile, they are mostly between 20 and 30, and the majority of them women. It must also be said that another characteristic of UNED students is that they combine work and study -that is their main reason for choosing a distance learning tertiary institution. As for their knowledge of the foreign language they have taken up, only $8 \%(\mathrm{~N}=32)$ claim not to have previous knowledge and most of them acknowledge being basic foreign language users (either beginner [A1] or elementary [A2] ), following the CEFR (Council of Europe, 2001). In terms of their previous use of audiovisual learning materials, $77 \%(\mathrm{~N}=318)$ considered that audiovisual materials are a very adequate digital resource for online learning, but only $5.6 \%(\mathrm{~N}=23)$ used them frequently. In terms of students' expectations before the project, the vast majority $(\mathrm{N}=327 / 79 \%)$ expected the video lessons to be useful for their language learning and $82 \%$ $(\mathrm{N}=338)$ assured that these materials would help mitigate the "sense of distance".

The number of students who finished the activity and filled out the final survey reached 174 , that is, $42 \%$ of those who started it. This disparity between the number of participants who completed the initial survey and those who also filled out the final one is not surprising in the context of distance education. It is not uncommon to have large numbers at the beginning of the academic year which dwindle as the course progresses and it is linked to their other responsibilities apart from studying, as previously explained. Furthermore, this was not a compulsory part of the course, so only those with a genuine interest in this innovative experience engaged in it fully and completed every single questionnaire.

The format and technical aspects of the videos were addressed in the first place. This did not pose a problem for the completion of the project, since only $15.5 \%(\mathrm{~N}=27)$ of the students reported to have undergone technical difficulties, mostly related to sound and/or incompatibilities with the software and/or platform, such as Adobe Presenter no longer being available for Linux, or needing an update (for instance, a newer version of Real Player), etc. As for the device used to access the digital materials, it was mainly computers PCs or 
laptops $(\mathrm{N}=153 / 88 \%)$, to access the contents, and only a minority ( $\mathrm{N}=28 / 16 \%)$ opted for mobile devices such as smartphones or tablets. They showed to be satisfied with the software used to record the videos $(\mathrm{N}=156=90 \%)$, and also considered that the length of these video lessons was appropriate $(\mathrm{N}=150 / 86 \%)$.

With regard to the progress made in their language learning, the students' perception was that these video lessons had contributed positively towards their communicative competence. Breaking it down into the different linguistic skills, oral comprehension was the most favoured one, since $66.7 \%(\mathrm{~N}=116)$ affirmed that their oral comprehension had improved fairly or a lot, whereas only half $51.1 \%(\mathrm{~N}=89)$ felt that their reading comprehension had advanced fairly or a lot, the same percentage as oral production, and the least favoured one was written production, since less than half of the students $(\mathrm{N}=80 / 46 \%)$ thought that it had been improved through this project. These results are in line with the type of digital materials offered: short video classes may deal with issues related to any aspect of language learning (covering all language skills), but the skill that is mostly practiced is oral comprehension, since the students have to make the effort to listen and understand what the teachers are saying -the videos were recorded in the target language. As an added value, students also reported to have improved their grammatical knowledge and lexis, thanks to the tips provided in those short video lessons.

They maintained to have encountered very few difficulties throughout the project, and those were mostly related to technical issues, until they found out what software they needed in order to watch the videos correctly, or due to a poor Internet connection in their devices. Some suggested uploading the videos onto a platform that enabled accessing them after the course was over, and the teaching teams are looking into the possibility of using iTunes $U$ (www.uned.es/itunesu), the educational section of Apple's iTunes Music Store, devoted to educational audio and video files from universities. Another suggestion for improvement is the quality of the recordings. The teachers' expertise in this varied, and a few videos were identified as lacking good sound, with an echo that made it difficult to hear clearly. Accessibility issues also came up, with one student asking for the inclusion of captions in the future. This will help those with hearing disabilities but also students with a poor foreign language competence.

\section{Conclusion}

This paper provides an overview of the research network for teaching innovation carried out by the authors, together with other colleagues, with the aim of improving the multimedia resources in their courses, and looking at the impact these tailor-made short video lessons would have in the students' linguistic competence. This study takes into consideration the learners' perspective, measuring their perceived progress and acceptance of this methodological innovation. Review of the abundant literature on the matter has shown that the use of videos for online language teaching and learning is widely accepted to be beneficial, with empirical evidence showing that it gives the opportunity of self-paced learning and provides distance learning students with a feeling of closeness, making the process more personalized. Video classes also provide examples of real language use and enhance comprehension in foreign languages, since learners tend to rely heavily on visual aids in this discipline. Research also 
covers some technical aspects of video lessons, such as their length, advised to be limited to a maximum of 10 minutes, given that it is easier to upload a short video on the Internet and it has proved to be more engaging for students.

As for the results of the qualitative study carried out, the initial hypothesis (short video lessons can impact positively in online students' progress, helping them improve their language competence) has been confirmed. The students' perception was measured and shown to be positive, valuing the different software used for the recordings and claiming that their linguistic skills, especially their oral comprehension, had improved. They also affirmed to have consolidated their grammatical and lexical knowledge. Their keen interest and participation and their positive assessment of the project in the final survey have increased their motivation towards foreign language learning, making them devote more time to this subject, which has a benign effect on their progress and marks. It would be desirable to continue this initiative and widen the number of video classes produced, especially now that there is the option of storing these multimedia files in an online platform (iTunes U) which is not constricted by the academic calendar and students' request to take accessibility into account will also be considered by the teaching teams. In this respect, it is worth mentioning that a follow-up is being currently devised, in order to evaluate more closely the benefits of this pedagogical intervention. This has not been possible beforehand due to lack of funding.

\section{REFERENCES}

Bryman, A. (2006). "Integrating quantitative and qualitative research: How is it done?", in Qualitative Research, 6: 97-113.

Çakir, I. (2006). "The use of video as an audio-visual material in foreign language teaching classroom", in The Turkish Online Journal of Educational Technology, 5(4), article 9.

Castrillo de Larreta-Azelain, M. D. (2014). "Language Teaching in MOOCs: the Integral Role of the Instructor”, in E. Martín-Monje \& E. Bárcena (eds.), Language MOOCs. Providing Learning, Transcending Boundaries. Berlin: De Gruyter Open, 67-90.

Council of Europe (2001). Common European Framework of Reference for Languages: Learning, Teaching, Assessment. Cambridge: Cambridge University Press.

Canning-Wilson, C. (2000). "Practical Aspects of Using Video in the Foreign Language Classroom". The Internet TESL Journal, VI(11), available from http://iteslj.org/Articles/Canning-Video. html, accessed 12 June, 2015.

Cohen, L., Manion, L. \& Morrison, K. (2007). Research Methods in Education. Routledge: London.

Conole, G. (2013). A new classification for MOOCs, available from http://e4innovation.com/?p=727, accessed 16 June, 2015.

Burt, M. (1999) Using Videos with Adult English Language Learners, available from http://www. cal.org/caela/esl_resources/digests/video.html, accessed 16 June, 2015.

Engin, M. (2014). "Extending the flipped classroom model: Developing second language writing skills through student-created digital videos", in Journal of the Scholarship of Teaching and Learning, 14(5): 12-26. doi: 10.14434/josotlv14i5.12829, available from http://josotl. indiana.edu/article/view/12829/19590, accessed 14 June, 2015.

Grotjahn, R. (1987). "On the methodological basis of introspective methods", in C. Faerch \& G. Kasper (eds.), Introspection in Second Language Research. Clevendon Avon, England: Multilingual Matters, 54-81. 
Guo,J., Kim,J. \& Rubin,R. (2014). "How video production affects student engagement: An empirical study of MOOC videos", in L@S '14 Proceedings of the first ACM conference on Learning@ scale conference. New York: ACM, 31-40.

Jeng, Y.L., Wang, K.T. \& Huang, Y.M. (2009). "Retrieving video features for language acquisition", in Expert Systems with applications, 36(3): 5673-5683.

Koumi, J. (2009). Designing Video and Multimedia for Open and Flexible Learning. New York/ London: Routledge.

Lackner,E. (2014). "Didaktisierung von Videos zum Einsatz in (x)MOOCs. Von Imperfektion und Zwischenfragen", in K. Rummler, (ed.), Lernräume gestalten - Bildungskontexte vielfältig denken. Münster, Germany: Waxmann, 343-355.

Lehmann, B. (2013). MOOCs - Versuch einer Annäherung. In R. Schulmeister (ed.), MOOCs Massive Open Online Courses. Offene Bildung oder Geschäftsmodell? Münster, Germany: Waxmann, 209-238.

Letón, E.; Durbán, M.; D’Auria, B. \& Lee, D.J. (2009). Self learning minivideos through Internet and mobile telephones: a help to the student in the Bologna process. EDULEARN 2009. Available from http://www.iated.org/concrete2/paper_detail.php?paper_id=5950, accessed 10 June, 2015.

Letón, E., García, T., Prieto, Á. \& Quintana, I. (2010). "Diseño y elaboración de mini-vídeos docentes mediante "Conferencia On-Line", in Proceedings of the XV Congreso Internacional de Tecnologías para la Educación y el Conocimiento. Available from http://www. ia.uned.es/minivideos/publicaciones/2010_cie_el_tg_ap_iq.pdf, accessed 10 June, 2015.

Lipson, K. (2013). "Dealing with megaclasses in an online environment", in Proceedings of the 59th ISI World Statistics Congress. Available from http://www.statistics.gov.hk/wsc/ IPS040-P3-S.pdf, accessed 11 June, 2015.

Pascual, M. A. (2011). "Principios pedagógicos en el diseño y producción de nuevos medios, recursos y tecnologías", in M.L. Sevillano (coord.) Medios, recursos didácticos y tecnología educativa. Madrid: Pearson Educación, 89-101.

Robson, C. (2002). Real World Research: A Resource for Social Scientists and PractitionerResearchers. Oxford: Blackwell Publishing.

Schulmeister, R. (2013). "Der Beginn und das Ende von OPEN. Chronologie der MOOCEntwicklung”, in R. Schulmeister (ed.), MOOCs - Massive Open Online Courses. Offene Bildung oder Geschäftsmodell? Münster, Germany: Waxmann, 17-59.

Seliger, H.W. \& Shohamy, E. (1990). Second language research methods. Oxford: Oxford University Press.

Wedekind, J. (2013). "MOOCs - eine Herausforderung für die Hochschulen?”, in G. Reinmann, S. Schön \& M. Ebner (eds.), Hochschuldidaktik im Zeichen der Heterogenität und Vielfalt. Norderstedt: Books on demand, 45-59.

Wright, A. (1976). Visual Materials for the Language Teacher. Essex: Longman. 